\title{
PUBLIC WELFARE ADMINISTRATION UNDER THE SOCIAL SECURITY ACT
}

\author{
FRED K. HOEHLER*
}

The administration of public welfare during the depression has been referred to as "America's leading industry": a caustic paradox which may serve at least as a starting point for better understanding of some recent developments in this field.

Industry expands during prosperous years. The business of caring, at government expense, for those who need help expands when hard times come upon us. 'The expansion of industry is hopefully anticipated. The expansion of our public welfare services is too often forced upon us by adversity and finds us unprepared. Everyone hopes that prosperity will endure. Everyone hopes that adversity will be short-lived. Both have their popular slogans, but the catchwords of a business boom are carefully planned to intrigue the public fancy, while the phraseology of welfare administration is wrung from the popular need.

Such a phrase is "social security," a recent addition to the vocabulary of every political unit in the United States. To the great majority it is still only a phrase with little realization of its significance either to the administrators who use it or the communities they serve.

One more up-side-down comparison before we leave this introductory thought: the expansion of private industry has a minimum of dependence on our local, state or national statutes, modified and regulated though it is by all three; but growth in public welfare service must wait for the official sanction of legislative bodies, and is rooted and grounded in the law. It cannot be coördinated, it cannot be planned on a national scale, until our local, state and national law is so coördinated and so planned.

At the beginning of the depression our local public welfare law, from coast to coast and Canada to Mexico, was a curious growth of tradition and expediency. Ancient customs and precedents, brought from older countries and planted in fortyeight states, had taken root, grown, or lain dormant in an amazing diversity of patterns. Uniformity there was none. "Adequacy" depended on climate, culture,

* B.S., I915, Pennsylvania State College. Director, American Public Welfare Association, since 1936. Director of Public Welfare, Cincinnati and Hamilton County, Ohio, and Director of Safcty, Cincinnati, 1928-1935. Lecturer on Public Welfare Administration, University of Chicago, since 1936. Lecturer on Public Administration, University of Cincinnati, r930-1935. Contributor to periodicals. 
racial or religious influence, that educational intangible loosely called "social mindedness," and many other factors.

We have just lived through one of our periods of expansion in public welfare service. The widespread unemployment of the past five years has forced new developments unparalleled in the history of the United States. Because of the severity of this depression, and the suddenness with which it came, emergency acts in every part of this country have created new state and local bodies for the administration of relief. Many of these bodies were literally built overnight, in response to desperate need which everyone hoped would be brief. The duration of the crisis, and its national scope, at length compelled federal action, first by the Reconstruction Finance Corporation and later by the Federal Emergency Relief Administration. Policies and procedures were dictated from above, and a national plan was created by emergency legislation, using local machinery wherever possible and creating new machinery wherever necessary for the distribution of what would, in any other age, have seemed fantastic sums of money in the care of hosts of American citizens.

Considering the chaos out of which this plan evolved and the swiftness with which it was constructed, the result - on the whole-has been surprisingly orderly and efficient." Considering that it was superimposed from above without time for the slow processes of education to create popular support, no one could believe that it would be anything but temporary.

The Federal Social Security Act is a recognition by our national government that the emergency is passing. It is an admission that public welfare services are a necessary and permanent function of the federal government. It is a step toward national uniformity, adequacy, and coördination.

\section{FEDERAI AID Is Not NEW}

There is no radical departure from precedent in the assistance titles of this Act. The aged, the blind, dependent children and their mothers have long been the wards of state and local governments. Maternal and health care are accepted responsibilities of the public servants who administer our taxes. Grants-in-aid by the national government to the several states are not new. Federal funds have been made available to highway departments, school systems and other educational institutions on the basis of qualified service and personnel. Every motorist who crosses a state line on a federal highway can testify to the convenience and comfort of this well-established principle. Every child who has been trained in an educational institution participating in the system is another witness for the success of such federal-state partnership. Indeed, we have recognized the premise so thoroughly that we have forgotten it, and now take it as a matter of course.

In the assistance phases of the Social Security Act, the same principle is merely expanded to include welfare services which local communities cannot possibly meet because of the increasing need for public aid and the inadequacy of both local funds 
and local channels of government through which funds may be efficiently administered.

For the reasons stated at the beginning, and for many other reasons, public welfare administration as a coördinated function of state governments has been woefully neglected. In spite of steadily increasing appropriations for welfare and relief, we have, as a nation, disregarded this type of intelligent planning. Sound policies and wise administration are so rare in the coast-to-coast picture that they stand out, here and there, as shining examples. The prevailing feeling of the general public is that the care of those in need can be carried on by government as it was formerly in much the same way that it is administered by lodges, churches, and the more rudimentary forms of private charity. The huge sums now being spent for these purposes place obligations on the state far beyond such-sporadic and hand-to-mouth efforts.

\section{Administrative Requirements of the Federal Act}

Few of our states are now eligible for the benefits conferred by the Social Security Act, as interpreted by the Social Security Board. New legislation, everywhere, is being planned or passed to qualify for these benefits. Public officials from coast to coast are asking in honest perplexity, what must be done to secure the best results in serving those who have been promised "social security."

To this question the Social Security Act itself does not afford a complete answer. In its provisions for grants-in-aid to states for old-age assistance, for aid to dependent children, maternal and child health services, and to crippled children, and aid for child-welfare services, the Act stipulates among the conditions on which these grants will be given requirements which relate to administration, ${ }^{1}$ but these requirements are couched in very general terms. A survey of these provisions will illustrate this fact.

a) In all these titles there is the requirement that the state plan provide either for its administration by a state agency or for the supervision of its administration by a state agency. In Titles $\mathrm{I}, \mathrm{IV}$, and $\mathrm{X}$, relating to old-age assistance, aid to dependent children, and aid to the blind, respectively, the state agency is not designated beyond the requirement that it be a "single" agency." Under Part I of Title V providing aid to maternal and child health services, the agency must be "the State health agency"; in Part 3 of that title providing aid to child welfare services, reference is made to "State public-welfare agencies." No specification of the character of the

${ }^{1}$ Title VI, "Public Health Work," of the Social Security Act, 49 STAT. 620 (1935), in providing in $\$ 60 \mathrm{r}$ an appropriation of $\$ 8,000,000$ "for the purpose of assisting states, counties, health districts," etc., "in establishing and maintaining adequate public-health services, including the training of personnel" does not provide the apparatus of conditions to be met by state plans. However, the money paid to any state must be expended "in accordance with plans presented by the health authority of such state and approved by the Surgeon General of the [Federal] Public Health Service." Id. $\$ 602$ (d). The power to withhold approval of state plans gives to the Surgeon General some control over state administration.

${ }^{2}$ Social Security Act, Tit. I, \$2 (a) (3); Tit. IV, $\$ 402$ (a) (3); Tit. X, 51002 (a) (3).

"Id., Tit. V, $\$ 503$ (a) (2). Presumably this agency would be the same as "the health authority" seferred to in Title VI. See note I, supra.

'Id., 5521 (2). 
"state agency" is made in Part 2, providing aid to services for crippled children." In Parts $I$ and 2 of Title $V$ special provision is made for "coöperation with medical, nursing and welfare groups and organizations" 6 and, in Part 2, "with any agency in such State charged with administering State laws providing for vocational rehabilitation of physically handicapped children."7

b) In Titles I, IV, and X, it is required that the plan adopted "be in effect in all political subdivisions of the State, and, if administered by them, be mandatory upon them." No such requirement is made in Parts $x, 2$, and 3 of Title V providing grants-in-aid of maternal and child health services, services for crippled children, and child welfare services respectively. Instead, in Parts I and 2, the purpose of the grants is specified to be for the aid of the state services "especially in rural areas and in areas suffering from severe economic distress." In Part 3, aid to "predominantly rural areas" is specified as the purpose, although expenditures in "other areas of special need" are also authorized. ${ }^{10}$

c) The plans for old-age assistance, aid to dependent children, aid to the blind, aid to maternal and child health services, and aid to services for crippled children must provide "methods of administration (other than those relating to selection, tenure of office, and compensation of personnel) as are found by the Board ${ }^{11}$ to be necessary for the efficient operation of the plan."12

d) The plans for the services listed in the preceding paragraph must also "provide for the making of reports" by the state agency "in such form and containing such information as the Board ${ }^{13}$ may from time to time require, and comply with such provisions as the Board may from time to time find necessary to assure the correctness and verification of such reports."14

The generality of the statutory requirements, coupled with the power of the federal administrative body to withhold approval of state plans or to withdraw approval when it is found, after notice and hearing, that a state has failed "to comply substantially" with any of these requirements "in the administration of its plan"10 results in a broad grant of discretionary power to the federal agencies, but it is to be presumed that in its exercise a wide range of choice will be left to the states.

Especially in the matter of personnel, much latitude of choice is conferred on the states by the Social Security Act. With this latitude goes a heavy responsibility, since it is axiomatic that a sound personnel policy is essential to administration that

${ }^{5} I d . \$ 513$.

${ }^{0} I d . \$ \$ 503$ (a) (6), 513 (a) (6). IId. $\$ 51 ?$ (a) (6).

${ }^{3}$ Id., Tit. I, $\S 2$ (a) (I); Tit. IV, $\$ 402$ (a) (I); Tit. X, \$1002 (a) (I).

${ }^{8} I d$. Tit. V, $\$ \$ 50 \mathrm{r}, 5 \mathrm{II}$.

${ }^{10} I d . \$ 521$.

"In the case of services for maternal and child health and crippled children, the Scerctary of Labor.

${ }^{23} I d$., Tit. I, $\$ 2$ (a) (5); Tit. IV, $\$ 402$ (a) (5); Tit. X, $\$ 1002$ (a) (5); Tit. V, $\$ 503$ (a) (3), 513 (a) (3). In clause (6) of the paragraphs in Titles I, IV, and X cited above, there is the further requirement that the plan "provide for granting to any individual, whose claim with respect to [the aid given thercunder] is denied, an opportunity for a fair hearing before such State agency."

${ }^{13}$ See note II, supra.

14 Id. Tit. I, $\$ 2$ (a) (6); Tit. IV, $\$ 402$ (a) (6); Tit. X, $\$ 1002$ (a) (6).

${ }^{25}$ Id. Tit. I, \$4; Tit. IV, \$404; Tit. V, \$\$505, 515; Tit. X, \$1004. 
will protect both public funds and the human beings for whose benefit they are to be used. Careless and inadequate administration or a poor selection of personnel by state and local governments may easily wreck the entire system. Honest officials, sincerely anxious for its success, would do well to observe carefully the suggestions of the Social Security Board on administrative policy.

\section{THE FIRST Step}

Where regular departments of government exist to which the new social security functions may be delegated, the obvious first step is to employ them. When there are no such departments as permanent parts of a state set-up, they should be created and empowered to administer these welfare activities. It is hazardous and extremely unsound to relate such services to any emergency administration which, by its very nature, cannot be expected to provide continuity of service and personnel. These new activities in the public welfare field are one of the largest and most important responsibilities of present and future government. The size of the job, the amount of money involved, the millions of men, women and children to whom even partial "security" is promised, and the army of employees to be enlisted in these services create a problem which demands trained and efficient personnel and the assurance of continuing policies in the conduct of public departments. Good civil service or a merit system should be invoked before appointments are made, and so far as possible all the functions of state government in the welfare field which deal with the federal government should be centered in one department or under one administrative head.

A few years ago we heard much bitter criticism, from the opponents of such legislation, about social security administration in Europe. "We hear less today, perhaps because it has not only weathered the depression, but come through it with improved standards. Russia is, of course, the outstanding exception; but the abolition of social insurance in Russia can hardly be laid at the doors of the depression.

- The reason for this achievement in England, France and Germany is that from the beginning administration of these measures has been non-partisan, efficient and carried out by carefully selected personnel. In the United States, unfortunately, thirty-eight states are still in the clutches of the spoils system. Wherever political influence is strongly felt we may expect, and we uniformly find, frequent changes in personnel and low standards of administration.

Any intelligent layman can see the dangers of political domination in this most human form of government; but so far, in this country, the forces of greed and the possibilities of patronage have won the day. The inertia of the general public is partly to blame. An alert and vigorous effort must be made by good citizens everywhere to safeguard administrative standards if the whole social security program. is to be protected from devastating sabotage by rival political groups. 


\section{State Administration}

Legislative provision must reinforce public opinion in a determined campaign to protect this program. Previously in this article it was suggested that all the assistance phases of this act should function through on $\epsilon$ governmental department. Necessarily, this department should be built into the regular governmental structure, but it should have the additional protection of laws which provide for a board with overlapping terms of service. In this way continuity of policy and procedure can be assured.

Committees and commissions of laymen and public welfare officials in many states are giving serious attention to the type of permanent organization which should succeed the emergency program. The Sherrill Committee in Ohio and the New York Commission appointed by Governor Lehman have made detailed reports which include thoughtful recommendations on administration and personnel.

In Ohio, the Sherrill Commitee, after a thorough discussion of the subject of an administrative board for the State Department of Public Welfare, decided to recommend a board with advisory powers. The report states;

"To overcome possible political exploitation of the office of Director or Commissioner of Welfare, many well-informed persons contend that a board rather than the Governor should be given the power of appointment. This has been highly effective in some states as a bulwark against politics.

"This method of appointment, however, has its disadvantages. Experience has shown that it is quite possible to get a poorly qualified board. In such case a governor, however desirous of improving the situation, is handicapped in replacing an incompetent department head.

"The board plan, furthermore, while it may succeed in keeping in office a department head well qualified for his duties, may at the same time handicap the Department from the standpoint of securing the active interest of the Governor and in securing for the Department a fair consideration of budget requirements." 16

In New York State, the Commission on State and Local Relief Policy appointed by Governor Lehman has assumed practically the same position. It is felt by both these bodies that the most advantageous arrangement would provide a board with advisory or limited administrative powers. Both commissions also recommend that the Director of the State Department of Public Welfare should be appointed by the Governor.

.The Sherrill Committee has this to say in reference to the Director:

The Director should be a person of wide and successful experience as an executive in the field of public welfare. He should be a student of social problems and have a good general understanding of the nature, significance and control of the large social problems which constitute the responsibility of the Department. A number of different professions are engaged in carrying out various phases of the work of the Department and the Di-

${ }^{10}$ Committee on Dep't of Public Welfare (Samuel Ash, Chmn.), Organization and Personnel of State Department of Public Welfare; General Recommendations, in Oho State Government Sunvey (1935) (Col. C. O. Sherrill, Dir.) p. 4 . 
rector (and also the Assistant Director) should understand how to utilize and focus the services of these various professional groups in order to deal most effectively with the social problems involved.

"The Committee is fully in accord with the viewpoint that the head of the Department should be appointed and tenure of office on a merit rather than on a political basis. This survey has revealed in no uncertain terms that political appointments in the Welfare Department have sacrificed the interests of thousands of helpless wards of the state."17

A suggested plan for the organization of a State Department of Public Welfare, prepared by the American Public Welfare Association, is presented below:

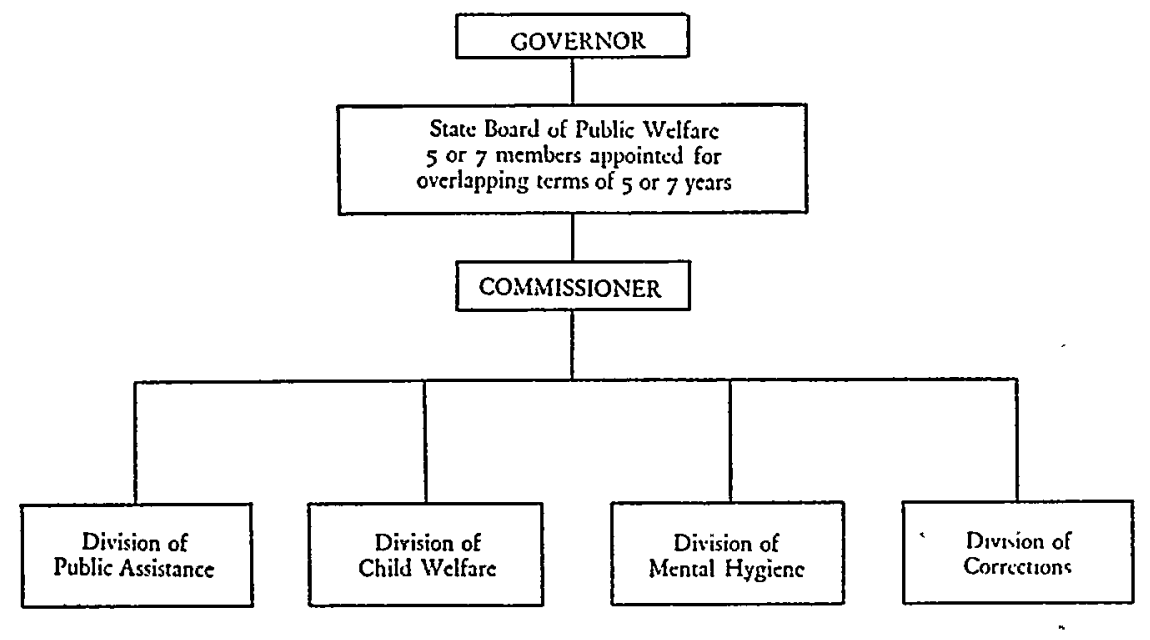

Competent Personnel

The question of whether the board should have advisory or administrative powers may still be open to debate. Public officials have not yet come to a unanimity of opinion on this point. There is, however, no room for question as to its responsibility for establishing standards of administration, continuity and adequacy of service, and excellence of personnel. These are matters of such vital importance that they must be in competent hands. Returning, for a moment, to the quotation with which this article began: it is at least as important-to many of us it seems more importantthat public servants employed to administer public funds in aiding those of our citizens who ask assistance from the government should be chosen with the same care that is used in staffing a bank or a large insurance company. "America's leading industry" might well follow the example of successful administrators in private business, where keen competition ensures meticulous attention to the choice of personnel.

Competence at the top means efficiency in the ranks. Only staff members equipped with adequate education and seasoned by experience can give constructive supervision to local departments. Although much of the present hostility toward college graduates and trained workers can be dismissed, in a pre-election year, as a political smoke screen, and although much of it is a natural reaction of local com-

${ }^{17}$ Ibid. 
munities to a program which was born of their adversity and superimposed from outside and above without opportunity for building a background of wise interpretation to assure local support, it is disheartening when governors and influential politicians resort to the political trick of echoing such sentiments. They require the services of specialists in medicine or the law for their physical ailments or legal problems. They employ engineers to build their bridges, architects to design their homes, and experienced plumbers to replace a leaky faucet. They demand schooled tree surgeons to amputate dead branches and cement cavities in oaks and elms. But they complacently allow huge sums of money to be distributed for the relief of distress by political henchmen who know nothing of the intricate and delicate business of repairing broken lives, sustaining courage, and rebuilding self-respect. Not only the efficient and economical expenditure of public funds, but the service of human need demand, for this task, a carefully selected specialist. For it, we should choose men and women who have great human sympathy and understanding-and more: intelligence and skill which only comes through adequate training and experience.

It is imperative that the state administration be empowered not only' to establish and maintain its own personnel standards through civil service or the merit system, but to prescribe qualifications for personnel in the county, township or parish units.

\section{RECORDS AND REPORTS}

Accurate, complete and up-to-date records and reports of expenditures are certain to be one qualification demanded by the Social Security Board of any state benefiting under this act. From the smallest political unit up to the State Department of Public Welfare, no effort should be spared to have this part of the work done promptly and well. Nothing less than the best system of record keeping will ensure economy of operation and the elimination of possible waste.

But the most complicated system of record keeping is not the best. It may be the worst. Many fine experiments have failed because of unnecessarily complicated forms, reports and procedures, in the hands of stupid or untrained people. Again, in this instance, administrators must find and employ intelligent and experienced people. Records should be both simple and complete. The American Public Welfare Association has drawn up suggested forms for the use or adaptation of administrators in local units as well as state departments. Carelessness or neglect of these details in local units mean waste, delay and inefficiency higher up. The state administrator should be able, and should have the power, to establish rules for procedure, recording, the use of uniform record forms and the regular and prompt auditing of expenditures.

\section{Local Administration}

The nation-wide trend of thought among public officials is now toward local administration of funds, under state supervision. There is a decided preference for "home rule" rather than direct administration by the states. There are distinct advantages in this plan. One of the weaknesses of our emergency set-up has been the 
lack of local interest in and local responsibility for plans superimposed from above. If funds are administered by small political units, understanding and interest are bound to increase. The state may still control or supervise. It may even be empowered with such authority as that recommended by Governor Lehman's New York Commission:

"The powers of the State Department and State Board ... should include the power to make rules and regulations for the administration of home relief: the power to pay part of the salary for qualified local welfare personnel and the power to withhold state funds unless rules and regulations of the State Board are complied with."18

What political division should be chosen for local administration? In some states counties do not exist. In these the city or town must, of course, be the unit. But both the Sherrill Report in Ohio and the Governor's Commission in New York recommend the county as the logical political division for administrative purposes. To quote again from the New. York Commission, it believes:

"The rôle of the town to be constantly diminishing in relief administration. Many welfare services have already been transferred from a town to a county basis and are being provided by a county wide staff of employees. 19

"Relief administration in the towns is far from satisfactory from the viewpoint of either the relief recipient or the tax payer. ${ }^{20}$

In the field of county relief administration, the Commission urges that county directors of public welfare be appointed instead of elected."21

This point of view is reinforced, in the New York study, by a discussion of the political machinations to which relief officials often resort when seeking reëlection. We blame the official, in such cases, rather than the system which makes it difficult for him to act otherwise. Our present system has evolved slowly. It grew without plan or premeditation. We have now an opportunity to revise it. In framing our new welfare laws, can we not evolve a plan which will make it easy rather than difficult for public officials to be ethical, impartial and efficient?

Whatever the local unit, all the welfare functions should be centered in a department of public welfare, which should consist of a board with either advisory or administrative powers.

There are many arguments which might be advanced for county boards with advisory powers only, or with limited advisory powers. But to the writer of this article it seems that a local board, close to the work that is being done, might well be given more complete administrative authority than a state board which would necessarily be removed from the scene of action. The county board might even appoint its own director. Local interest everywhere needs building up, and interest goes hand in hand with responsibility. If adequate supervision is given and standards are maintained by the state authority, we need not be too fearful of the decentralization of administrative powers. Whatever the authority of the county board,

\footnotetext{
${ }^{18}$ Governor's Commission on Unemployment Relief, State and local welfare organization in the State of New York (x936) p. 65.

${ }^{20} I d .$, pp. 7I-72. $\quad{ }^{20} I d .$, p. 74. $\quad 21$ Id., p. 8I.
} 
it should be appointed, and the terms of its members should overlap. This is the only way in which continuity of policy can be assured.

The Governor's Commission in New York recommends:

"The County Commission of Welfare should be appointed by a majority recorded vote by the County Board of Supervisors. . . . In counties having an administrative head such as a county president or manager, the County Welfare Commissioner should be appointed by this chief executive."22

A suggested plan for the organization of a County Department of Public Welfare, prepared by the American Public Welfare Association, is presented below:

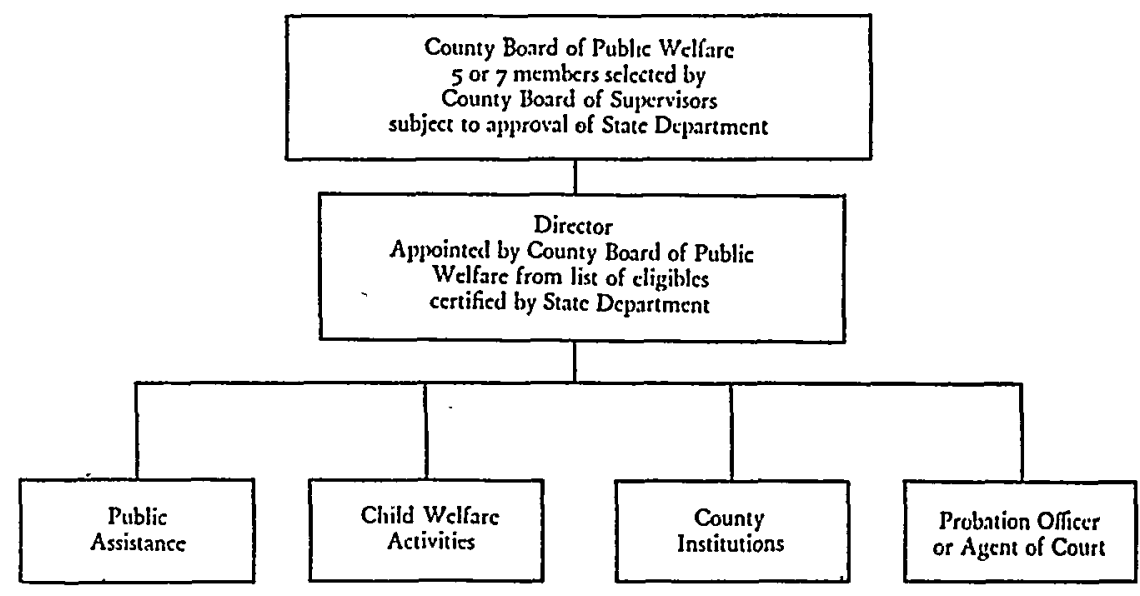

ConcLusion

The Social Security Act offers tremendous possibilities to the American people. Its strength or its weakness will depend on its administration. Its success depends on coopperation up from the smallest political units in remote corners of this country through the administrative machinery of forty-eight states to the Social Security Board in Washington. With sound administration, it will mark the greatest single advance in social legislation ever made in this country. Without sound administration, more money may be wasted under this act than ever before in the history of the United States.

Much latitude is left to the states, and we shall see experimentation with various methods. But in spite of our wide range of climate, culture, tradition and educational advancement, our brief experience under the Federal Emergency Relief has taught us that basic uniformity is possible on a national scale. Unless we insist upon intelligent, skillful personnel; unless we safeguard honest and efficient administration, our descent from the heights we have painfully reached in the passage of this act will be swift and terrible. If this tremendous experiment fails the hope of millions of helpless people will be betrayed, and "social security" in this country will be a dream we failed to realize.

Ibid. 